\title{
鋼管トラス梁の横座屈耐力に関する研究 \\ X型結構の分岐継手タイプ鋼管トラス梁について \\ STUDY ON LATERAL BUCKLING STRENGTH OF TUBULAR TRUSS BEAMS \\ Case of X-type tubular truss beams with branch joints
}

\author{
鈴木敏 郎*, 小河利 行**, 深 沢 隆*** \\ Toshirou SUZUKI, Toshiyuki OGAWA and Takashi FUKASAWA
}

\begin{abstract}
In the present study, we proposed the design formula of chord members of X-type tubular truss beams with branch joints. This formula is derived from the modified lateral buckling conditional equation obtained by the energy method, taking the constrained effect of rigid joints at crosing points of bracing members obtained by the results of the eigenvalue analyses into consideration. And also, we clarified quantitatively this effect to the lateral buckling behavior by the resuluts of the experiments and the non-linear analyses. Cosequently, we confirmed validity of the used assumptions and the proposed design formula.
\end{abstract}

Keywords : lateral buckling strength, buckling length coeficient, X-type tubular truss beam 横座屈耐力，座屈長さ係数，X型鋼管卜ラス梁

1.はじめに

トラス梁が横座屈する場合, 腹材, 引張弦材が圧縮弦 材の構面外への移動を拘束することから，その座屈荷重 は横補剛支点間距離を座屈長さとした圧縮弦材の座屈荷 重よりも高くなる。特に，鋼管断面を溶接によって直接 接合して製作された分岐継手タイプのトラス梁（以後, 鋼管トラス梁と呼ぶ）は，開断面形鋼で構成されるトラ 又梁に比較して構成部材の断面積に対するねじり剛性が 大きいこと，また接合部において特別の補強無しで剛節 に近い条件が得られることから横座屈に対して有利とな る。

坪井・若林 ${ }^{11}$ はこの問題に関し，トラス梁のねじり剛 性が横座屈耐力の増加に大きな役割を果たすことを理論 解析によって明らかにした。鈴木 ${ }^{2 i \sim 6)}$ は実験および理論 解析によりこのことを検証し，エネルギー法によって横 座屈条件式を導きトラス梁と等価な剛性を有する充腹梁 の設計式を準用する方法を示した。森”はホポンシャル エネルギーの停留原理からトラスの曲げねじれ座屈変形 に対する微分方程式を導き，さらに近似的に座屈変形様 式を仮定して軸力と曲げモーメントの相関関係式を求め た。藤本・難波 ${ }^{8}$ は立体座屈たわみ角法公式を用いてパ ラメトリックな数値計算を行い, 圧縮弦材の座屈長さを
与える設計図表を作成した。若林ら゙は種々の端モーメ ントを受けるトラス梁を対象にエネルギー法による横座 屈耐力と実験結果の比較を行った。また, 森野(10).11) は立 体座屈たわみ角法公式を用いて 2 - 格間ごとに横補剛 されたトラスが等曲げモーメントを受ける場合の節点荷 重あるいは材端曲げモーメントの影響を考慮した圧縮弦 材の座屈長さを与える略算法を示した。

以上の研究は主に弾性座屈を対象としており, 節点が 剛節であるという仮定を設けているが，松井ら ${ }^{12) .131}$ は立 体座屈たわみ角法公式を用いて非弾性座屈領域における 広範な数值計算を行い，それをもとにトラス梁圧縮弦材 の座屈応力度を与える実験式を示した。また，松井 ら ${ }^{14)-19)}$ は実験および立体座屈たわみ角法公式に基づく 解析により弦材主管の局部的な弾性変形の横座屈耐力に 及ぼす影響を明らかにし，この節点が半剛節であること を考慮した設計式を提案した。

しかしながら，上記の研究は主にシングルワーレン結 構（以後 $\mathrm{V}$ 型, $\mathrm{N}$ 型と呼ぶ）のトラス梁を対象としてお り，大スパン構造に適用される腹材交点部㴊節のダブル ワーレン結構（以後X型と呼ぶ）のトラス梁に関する実 験研究は筆者の知る限り行われておらず，腹材交点部剛 節の横座屈耐力に及ぼす影響は定量的に把握されていな
* 東京工業大学 教授 $\cdot$ 博士 (工学)

** 東京工業大学 助教授・博士 (工学)

****株式会社巴組鐵工所
Prof., Tokyo Institute of Technology, Dr. Eng.

Assoc. Prof., Tokyo Institute of Technology, Dr. Eng.

Tomoegumi Iron Works, Ltd. 
いのが実状である。

このことから，本研究では等曲げモーメント応力下の $\mathrm{X}$ 型結構の鋼管トラス梁を対象とした弾性固有値解析結 果を，文献 5)，6）に示されるエネルギー法に基づいて 導かれた横座屈耐力算定式を用いて整理する方法によ り，腹材交点部剛節の横座屈耐力に及ぼす影響の定量的 な把握を試みた。また，腹材交点部剛節のトラス梁の構 面外変形挙動, 弦材のねじれ変形挙動に及ぼす影響を実 験的に明らかにすることにより，上記解析結果の妥当性 の検証を行った。

\section{V型龬管トラス梁弦材の横座屈長さ係数評価}

\section{1 座屈長さ係数評価基本式}

構面内回転は自由, ねじり回転は拘束, 材軸方向移動 は自由, それ以外の移動は拘束の弦材端部境界条件（以 後境界条件 A 亡呼ぶ）における鋼管卜ラス梁が，Fig. 1 に示すようにその構面内材軸方向に外力を受けて横座屈 する場合の耐力は，弦材の圧縮力 $P_{1}=P_{c r}$ で表現する と, 文献6）の（6）（7）式より（1）式で表される。

$$
P_{c r}=(1+\alpha)(\pi / L)^{2} B_{c 1}
$$

$$
\alpha=\frac{C / H^{2}\left\{-P_{2}+(\pi / L)^{2} B_{c 2}\right\}}{(\pi / L)^{2} B_{c 1}\left\{-P_{2}+(\pi / L)^{2} B_{c 2}+C / H^{2}\right\}}
$$

$P_{i}:$ 弦材の軸応力（圧縮を十とする）

$C:=\delta_{1} C_{c 1}+\delta_{2} C_{c 2}+B_{w}+C_{w}$

$\delta_{i}:=1 /\left\{1+C_{c i} /\left(6 B^{\prime}\right)\right)$

$B^{\prime}:=\left\{L /\left.(\pi H)\right|^{2} \tan \phi \sin ^{3} \phi B_{b}\right.$

$B_{w}:=\cot \phi \sin ^{3} \phi B_{b}$

$C_{w}:=\tan \phi \sin ^{3} \phi C_{b}$

$B_{c i}:$ 弦材の曲げ成性 $=E I_{c i}$

$C_{c i}:$ 弦材のねじり剛性 $=2 G I_{c i}$

$B_{\mathrm{b}}$ : 腹材の曲げ埥性 $=E I_{b}$

$C_{b}:$ 腹材のねじり剛性 $=2 G I_{c i}$

$I_{c i}, I_{b}:$ 弦材, 腹材の断面二次モーメント
$E:$ ヤング係数
$G$ : せん断弾性係数
$L ：$ トス梁長さ
$H ：$ トスス梁デプス

ただし，下添字 1, 2 は玨縮弦材，引張弦材を示す。

この (1) 式を, 等曲げモーメント応力状態すなわち $P_{2}=-P_{1}=-P_{c r}$, かつ上下弦材のサイズが等しい場合 すなわち $B_{c 2}=B_{c 1}=B_{c}, C_{c 2}=C_{c 1}=C_{c}, \delta_{2}=\delta_{1}=\delta$ の 条件下において $P_{c r}$ について解くと（2) 式が導かれる。

なお, 以後の検討においては，特記のない限り等曲げ モーメント応力状態でかつ上下弦材のサイズが等しい場 合を対象とすることから，これらの説明は原則として省 略するものとする。

$$
\begin{aligned}
P_{c r}= & (\pi / L)^{2} B_{c}\left[1+2\{L /(\pi H)\}^{2} C / B_{c}\right]^{1 / 2} \\
= & (\pi / L)^{2} B_{c} \cdot\left[1+2\{L /(\pi H)\}^{2}\left(2 \delta C_{c}+B_{w}\right.\right. \\
& \left.\left.+C_{w}\right) / B_{c}\right]^{1 / 2} \ldots \ldots \ldots \ldots \ldots \ldots \ldots \ldots \ldots \ldots \ldots \ldots \ldots \ldots \ldots \ldots
\end{aligned}
$$

また, 座屈長さ $L_{k}$ の弦材のオイラ一座屈荷重 $P_{e}=$ $\left(\pi / L_{k}\right)^{2} B_{c}$ を（2）式の $P_{c r}$ に代入することにより，座 屈長さ係数 $L_{k} / L$ が $(3)$ 式の形で与えられる。

$$
\begin{aligned}
L_{k} / L= & {\left[1+4\left\{L /\left.(\pi H)\right|^{2} \delta C_{c} / B_{c}\right.\right.} \\
& \left.+2\{L /(\pi H)\}^{2}\left(B_{w}+C_{w}\right) / B_{c}\right]^{-1 / 4 \cdots \cdots(}
\end{aligned}
$$

\section{2 座屈長さ係数評価基本式の有効性の検証}

Fig. 2 に, Table 1 に示す $L / H$ を変化させた 3 ケ一

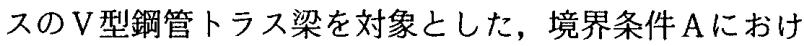
る $L_{k} / L$ と $I_{b} / I_{c}$ の関係を示す。

ここに，細実線は材軸方向，円周方向に積分点を有す るパイプ断面梁要素を適用した文献 21）に示す解析手 法による弾性固有値解析結果を, 細点線は（3）式によ る算定結果を示す。また，細一点鎖線は鋼管構造設計施 工指針・同解説 ${ }^{23)}$ の坐屈長さ評価式 (4) 式を用いた算 定結果を示す。なおこれらの算定および解析において， 2.3 に詳説するように, 弦材の節点部局部変形の影響は 無視するものとする。

$$
L_{k} / L=\left[1+0.078(L / H) T_{s}+\frac{0.25(L / H)^{3}}{0.8(L / H)+1 / B_{s}}\right]^{-1 / 4}
$$

$$
T_{s}=2 m\left(I_{b} / I_{c}\right) \quad B_{s}=m \sin ^{3} \phi\left(I_{b} / I_{c}\right)
$$

$m$ ：トラス梁を構成する腹材数

これより，細実線で示す（3）式による算定結果と細 一点鎖線で示す (4) 式による算定結果はいずれのケ一

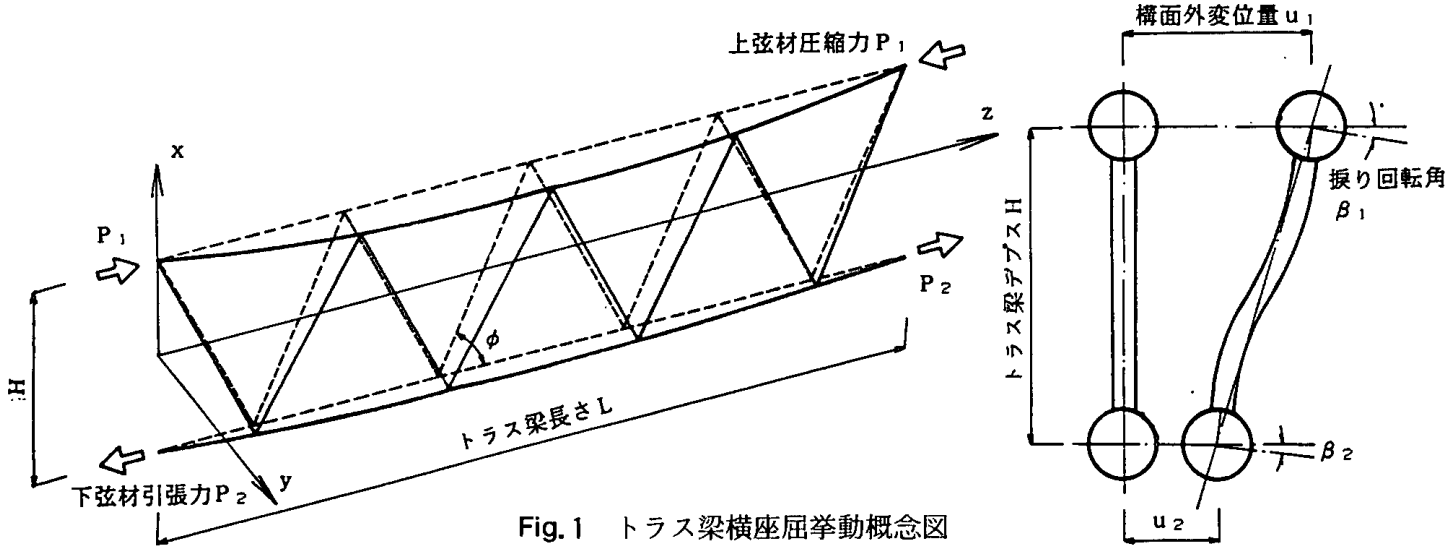


スにおいても良く一致している。また, 弾性固有値解析 結果に比べてやや大きめの値となり安全側評価を与え る。

\section{3 節点部局部変形の横座屈耐力に及ぼす影響}

Fig. 3 に文献 6)，18）における，弦材構面外細長比が

Table 1 V 型解析モデルリス卜

\begin{tabular}{|c|c|c|c|c|c|c|}
\hline $\begin{array}{l}E F^{\prime \prime} \\
\text { 名 你 }\end{array}$ & 弦材サイズ & $\begin{array}{c}\mathrm{L} \\
\text { (em) }\end{array}$ & $\lambda$ & $\begin{array}{c}\mathrm{H} \\
\text { (c口) }\end{array}$ & $\begin{array}{c}\phi \\
\text { (deg) }\end{array}$ & 㔭紫图 \\
\hline$v_{1}$ & \multirow{3}{*}{$\phi 101.6 \times 3.2$} & 150 & 43. & \multirow{3}{*}{75} & \multirow{3}{*}{$63^{\circ}$} & $\triangle$ \\
\hline $\mathrm{v} 2$ & & 300 & 86 & & & $\bowtie \bowtie$ \\
\hline $\mathrm{v} 3$ & & 450 & 129 & & & 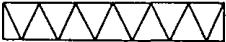 \\
\hline
\end{tabular}
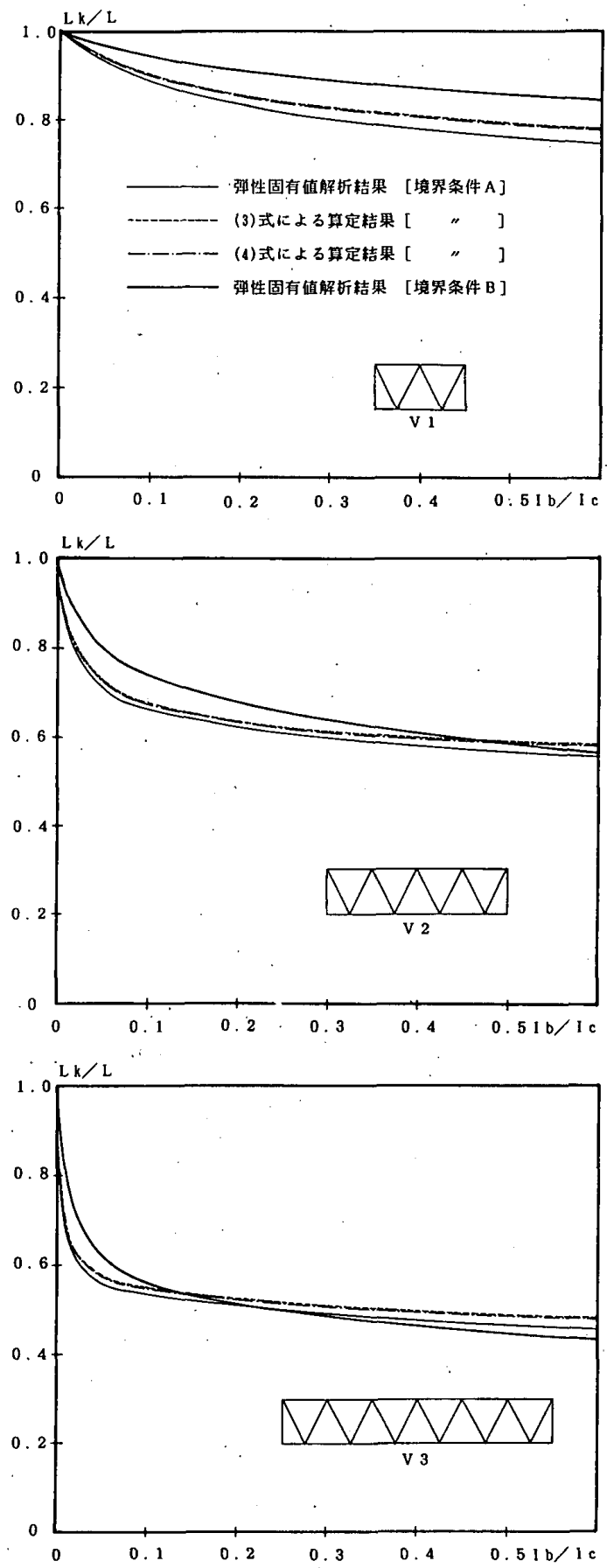

Fig. 2 V型トラス梁における $L_{k} / L-I_{b} / I_{c}$ 関係
118 より大きい領域を対象とした，境界条件 $\mathrm{A}$, 等曲げ モーメント分布のV型鋼管トラス梁弦材の座屈長さ係数 に関する, 横座屈耐力実験結果と弾性固有値解析結果の 比較図を示す。

このとき，実験における座屈長さは鋼構造設計規準・ 同解説 ${ }^{24}$ に定義する許容圧縮応力度式の安全率を外した

(5) 式を用いて評価する。

$\lambda \leqq \Lambda \quad \sigma_{c r}=\left\{1-0.4(\lambda / \Lambda)^{2}\right\} \sigma_{y}$

$\lambda>\Lambda \quad \sigma_{\mathrm{c} \tau}=\pi^{2} E / \lambda^{2}$

$$
\Lambda=\sqrt{\pi^{2} E /\left(0.6 \sigma_{y}\right)}
$$

$\sigma_{c r}$ : 座屈応力度 $\sigma_{y}$ : 降伏応力度 $\lambda$ : 絊長比

これより，算定結果は弦材の節点部局部変形の影響を 無視した条件における解析結果と良い対応を示してい る。

また，文献 14）によれば，単材では局部変形に伴う 節点の曲げ剛性低下は影著となるものの, トラスに組込 まれた場合においては，局部変形の影響を受ける腹材曲 げ㴊性よりむしろ局部変形の影響を受けない腹材的じり 剛性により弦材が補剛されることから，局部変形による 剛節度低下の横座屈耐力に及ぼす影響は小さいことが報 告されている。

このことから, 本論では節点部における弦材の局部変 形は無視するものとする。

\section{4 実験モデルの境界条件における座屈長さ係数評価 式の誘導}

Fig. 2 に，Fig. 4 に示す後述の実験モデルにおける， 圧縮弦材端部は構面内回転, ねじり回転共自由, 引張弦 材端部は構面内回転, ねじり回転共拘束, 構面外変形は いずれの材端においても拘束の境界条件（以後境界条件 B と呼ふ）における弾性固有値解析結果に基づく $L_{k} / L$ と $I_{b} / I_{c}$ の関係を太実線で示す。

境界条件 $\mathrm{A}$ においては $I_{b} / I_{c}$ が大きい場合は座屈長さ

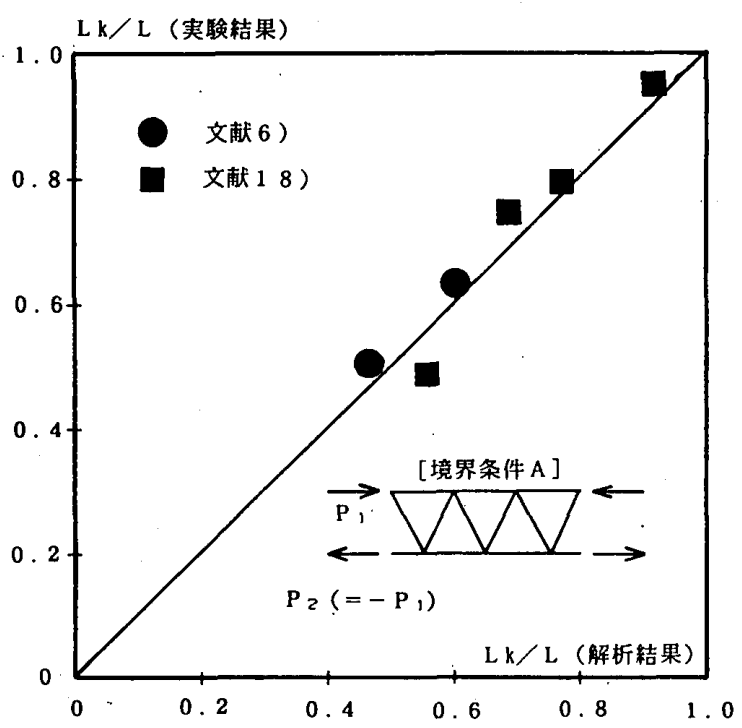

Fig. 3 V型トラ.ス梁における $L_{k} / L$ 比較図 
係数が収斂傾向にあり，（3）式におけるかっこ内の第 2 項の影響が支配的となる。

これに対し，境界条件Bにおいては境界条件 Aに比へ て，圧縮弦材端部のねじり回転が自由であることから第 2 項の影響が減少する傾向に, また引張弦材端部の回転 が拘束されることから第 3 項の影響が増大の㑯向にあ る。この結果, 座屈長さ係数は境界条件 $\mathrm{A}$ に比べると
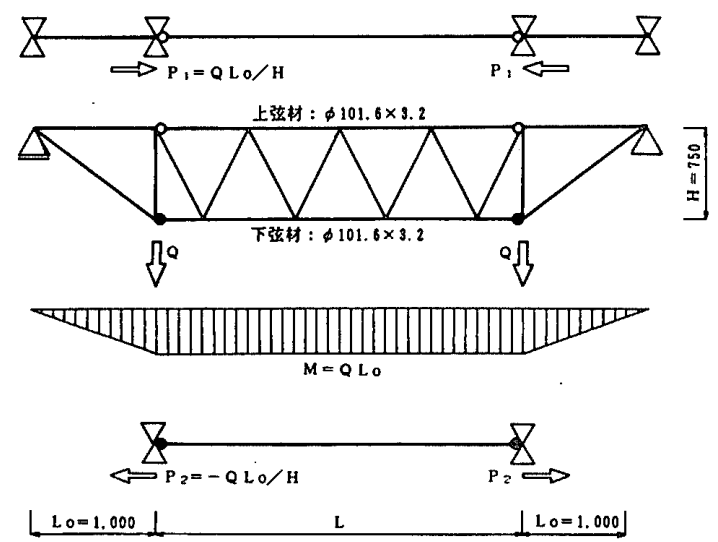

Fig. 4 実験モデル [境界条件 B] 概要図

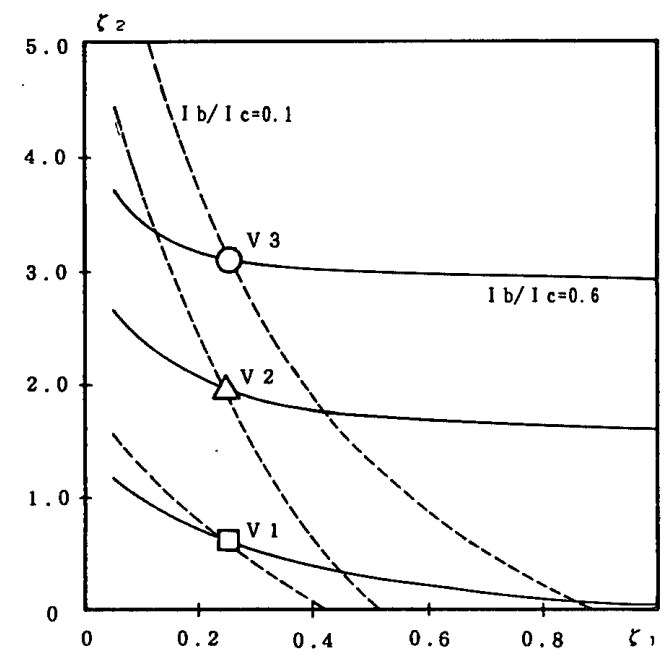

Fig. 5 V型トラス梁における $\zeta_{2}-\zeta_{1}$ 関係

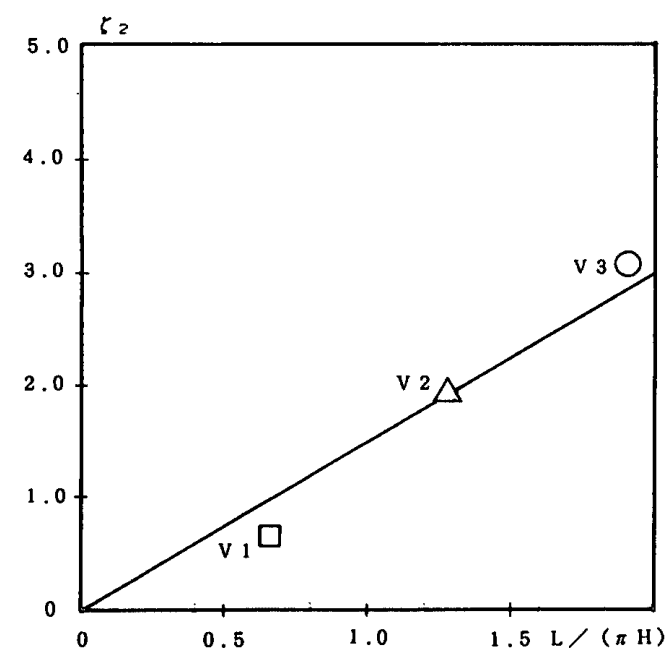

Fig. 6 V型トラス梁における $\zeta_{2}-L /(\pi H)$ 関係
$L / H, I_{b} / I_{c}$ が小さい場合には大きくなる傾向にあるが, $L / H$ かつ $I_{b} / I_{c}$ が大きい場合には逆に小さくなる。

このことから，境界条件 Bにおける座屈長さ係数評価 式として（3）式を補正した（6）式を考える。

$$
\begin{aligned}
L_{k} / L= & {\left[1+4\{L /(\pi H)\}^{2} \delta C_{c} / B_{c}\right.} \\
& \left.+2\{L /(\pi H)\}^{2} \zeta_{2}\left(B_{w}+C_{w}\right) / B_{c}\right]^{-1 / 4} \cdots(6) \\
\delta=1 /(1+ & \left.\left.C_{c} / 6 \zeta_{1} B^{\prime}\right)\right\}
\end{aligned}
$$

ここに, $\zeta_{1}, \zeta_{2}$ は補正係数を表す。なお，本報ではこ の補正係数を求好方法として, 弾性固有値解析結果に 基づいて二つの変数 $\zeta_{1}, \zeta_{2}$ が $I_{b} / I_{c}$ にかかわらず各ケー スごとに共通となる点を求める方法を採る。

Fig. 5 に, Table 1 に示す $L / H$ を変化させた 3 ケー スのV型鋼管トラス梁を対象とした, 弾性固有值解析結 果加逆算して求めた補正係数 $\zeta_{1}$ と $\zeta_{2}$ の関係を示す。 ここに実線は $I_{b} / I_{c}$ が 0.6 , 点線は 0.1 とそれぞれ代表 的なポイントにおける 2 点における結果を示す。

図中のプロット点は各ケースにおける実線と点線の交 点すなわち補正係数 $\zeta_{1}, \zeta_{2}$ が共通となる点を示す。なお， 他の $I_{b} / I_{c}$ における $\zeta_{1}-\zeta_{2}$ 関係曲線もこのプロット点近 傍を通ることを確認している。これより，原は $L / H$ に かかわらずほぼ一定 $\zeta_{1}=1 / 4, \zeta_{2}$ は $L / H$ にほぼ正比例 し, Fig. 6 より $\zeta_{2}=3 / 2\{L /(\pi H)\}$ とおける。したがって, 本研究範囲である $2 \leqq L / H \leqq 6, I_{b} / I_{c} \leqq 0.6$ において，

(6) 式は (7) 式の形で表される。

$$
\begin{aligned}
L_{k} / L= & {\left[1+4\{L /(\pi H)\}^{2} \delta C_{c} / B_{c}\right.} \\
& \left.+3\{L /(\pi H)\}^{3}\left(B_{w}+C_{w}\right) / B_{c}\right]^{-1 / 4} \cdots . .(7) \\
\delta=1 /(1+ & \left.+C_{c} /\left(3 / 2 B^{\prime}\right)\right\}
\end{aligned}
$$

Fig. 7 に，境界条件 B を対象とした（7）式による $L_{k} / L$ と $I_{b} / I_{c}$ の関係を細点線で示すが，太実線で示す 弾性固有值解析結果とおおむね良い対応を示す。このこ とから, 坐屈長さ係数評価式 (7) 式の有効性が確認さ れる。

\section{X型鋼管トラス梁弦材の横座屈長さ係数評価}

\section{1 腹材交点部剛節の横座屈耐力に及ぼす影響}

Fig. 8 に境界条件 B の腹材交点部を剛節としたX $\mathrm{X}$ 型鋼 管卜ラス梁の弾性固有值解析における $L_{k} / L$ と $I_{b} / I_{c}$ の 関係を示す。また，交点部に節点を持たない場合（以後 $\mathrm{X}^{\prime}$ 型と呼ぶ）の結果についても併せて示す。解析ケー スはTable 2 に示す $L / H$ を変化させたそれぞれ 3 種類 とする。

これより，図中太実線で示す X型は細実線で示す $\mathrm{X}^{\prime}$ 型に比べていずれのケースにおいても座屈長さ係数が小 さく, 腹材交点部剛節の影響が認められる。また, 細点 線は (7) 式に示す算定結果であり, 細実線で示す $X^{\prime}$ 型の結果と良い対応を示す。したがってX型剛節タイプ の横夾屈耐力評価においては, 新たに腹材交点部の影響 を考慮する必要がある。 


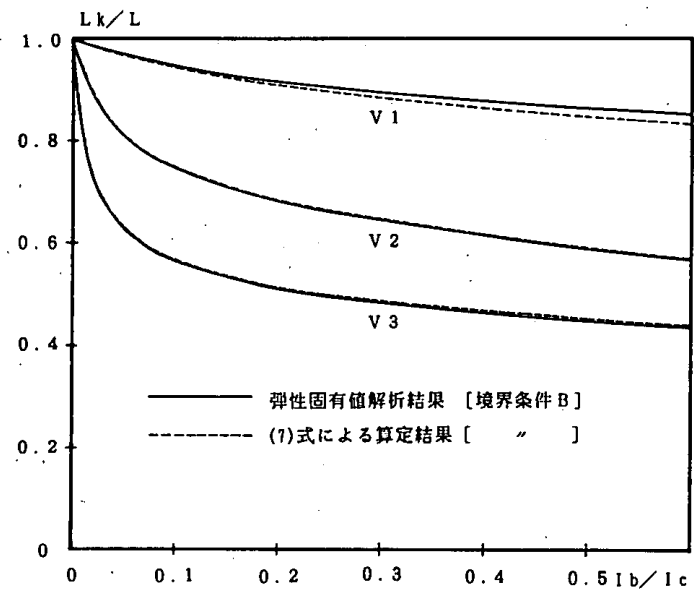

Fig. 7 V型トラス梁における $L_{k} / L-I_{b} / I_{c}$ 関係
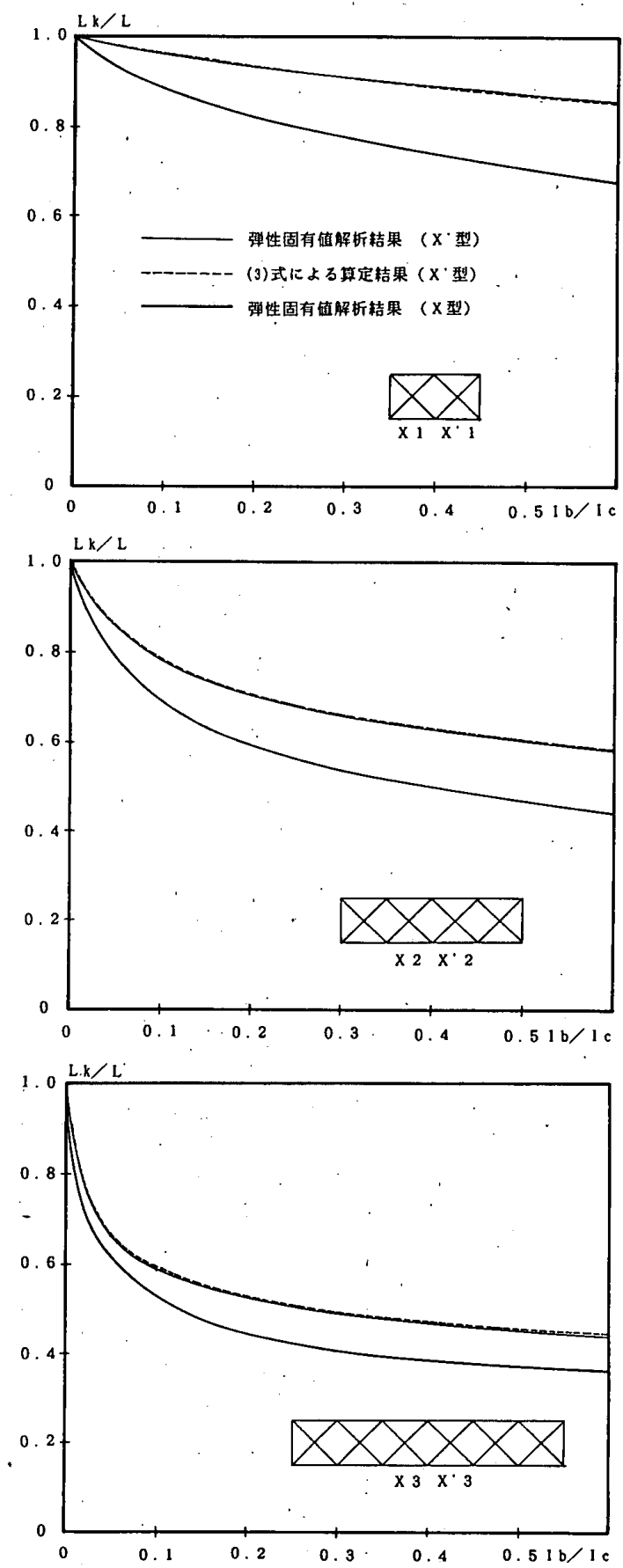

Fig. $8 \mathrm{X}, \mathrm{X}^{\prime}$ 型卜ラス梁における $L_{k} / L-I_{b} / I_{c}$ 関係
なお，X, $X^{\prime}$ 型における $I_{b}$ は腹材 1 本あたりの値, $\mathrm{X}^{\prime}$ 型における $B^{\prime}, B_{w}, C_{w}$ の值はV 型として算定した 値の 2 倍とする。また, V型の場合と同様, X 型につい ても等曲げモーメント応力状態を対象としていることか ら, 弦材節点の局部変形は無視するものとする。

\section{2 座屈長さ係数評価式の誘導}

Fig.8において，X型は $\mathrm{X}^{\prime}$ 型あるいは（7）式の結 果に比べ $I_{b} / I_{c}$ の影響が大きくなる傾向，言いかえれば (3) 式の右辺かっこ内の第 2 項の影響が小さく, 第 3 項の影響が支配的となる傾向にある。したがって, 境界 条件BにおけるX型鋼管トラス梁の座屈長さ係数評価式 として（3）式の第 2 項を省略した（8）式を考える。

$$
L_{k} / L=\left[1+2\{(L / \pi H)\}^{2} \eta\left(B_{w}+C_{w}\right) / B_{c}\right]^{-1 / 4}
$$

このとき, $\eta$ は補正係数であり弾性固有值解析結果か ら逆算して求める。

Fig. 9 に補正係数 $\eta$ と $I_{b} / I_{c}$ の関係を示す。これより 補正係数 $\eta$ は $I_{b} / I_{c}$ にかかわらず一定值，またその値は $L / H$ にほぼ正比例すると見なせることから, 本研究範 曲である $2 \leqq L / H \leqq 6, I_{b} / I_{c} \leqq 0.6$ において， $\eta=15 / 2$ $\{L /(\pi H)\}$ (Fig. 10参照) とすると, (8) 式は（9) 式 の形で表される。

$$
L_{k} / L=\left[1+15\{L /(\pi H)\}^{3}\left(B_{w}+C_{w}\right) / B_{c}\right]^{-1 / 4}
$$

\begin{tabular}{|c|c|c|c|c|c|c|}
\hline $\begin{array}{l}モ テ ゙ ル ~ \\
\text { 名 你 }\end{array}$ & 弦材サイス & $\begin{array}{c}\mathrm{L} \\
\text { (cm) }\end{array}$ & $\lambda$ & $\begin{array}{c}\mathrm{H} \\
\text { (ca) }\end{array}$ & $\begin{array}{c}\phi \\
\text { (deg) }\end{array}$ & 明 四 \\
\hline $\begin{array}{l}x=1 \\
x \times 1\end{array}$ & \multirow{3}{*}{$\begin{array}{c}\phi 101.6 \times 3.2 \\
=\end{array}$} & 150 & 43 & \multirow{3}{*}{75} & \multirow{3}{*}{$45^{\circ}$} & $\triangle \triangle$ \\
\hline $\begin{array}{l}x 2 \\
\times \cdot 2\end{array}$ & & 300 & 86 & & & ХХХ \\
\hline $\begin{array}{r}X_{3} \\
X \cdot 3 \\
\end{array}$ & & 450 & 129 & & & $\triangle \triangle \triangle \triangle \triangle X$ \\
\hline
\end{tabular}

Table 2 X型， $X^{\prime}$ 型解析モデルリスト

Fig. 11 に，境界条件Bを対象とした（9）式による $L_{k} / L$ と $I_{b} / I_{c}$ の関係を細点線で示すが, 太実線で示す 弾性固有值解析結果とおおむね良い対応を示す。このこ とから座屈長さ係数評価式 ('9) 式の有効性が確認され る。

\section{X型鋼管トラス梁の横座屈耐力試験}

\section{1 試験体の選定}

構面外細長比を $43,86,129$ 亡変化させた, 等モ一メ ント応力下における境界条件 $\mathrm{B}$, 上下弦部材サイズが等 しく腹材交点部が㴊節となるX型鋼管トラス梁 3 体につ いて横座屈耐力試験を行う。この்とき，トラス梁の形状 寸法, 弦材サイズは 3 章で実施した固有值解析における モデルと同一, 弦材と腹材の剛性比 $I_{b} / I_{c}$ は 0.05 と各 試験体一定する。 


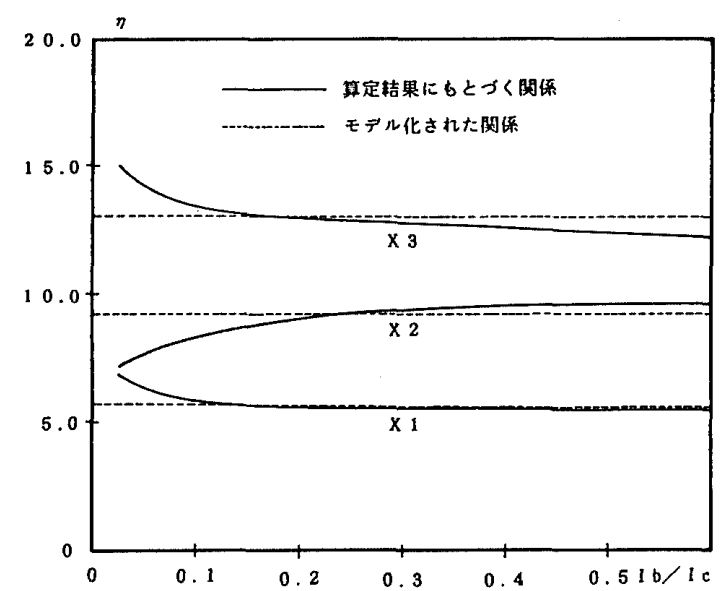

Fig. 9 X型トラス梁における $\eta-I_{b} / I_{c}$ 関倸

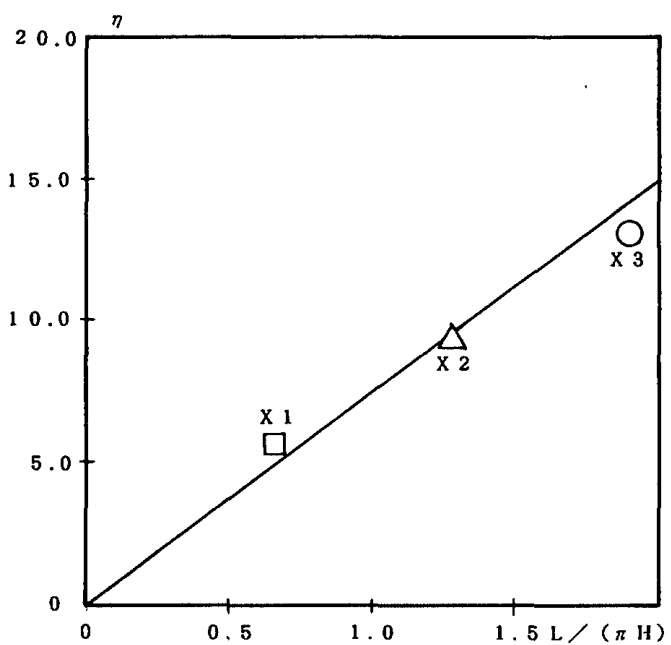

Fig. 10 X型トラス梁における $\eta-L /(\pi H)$ 関係

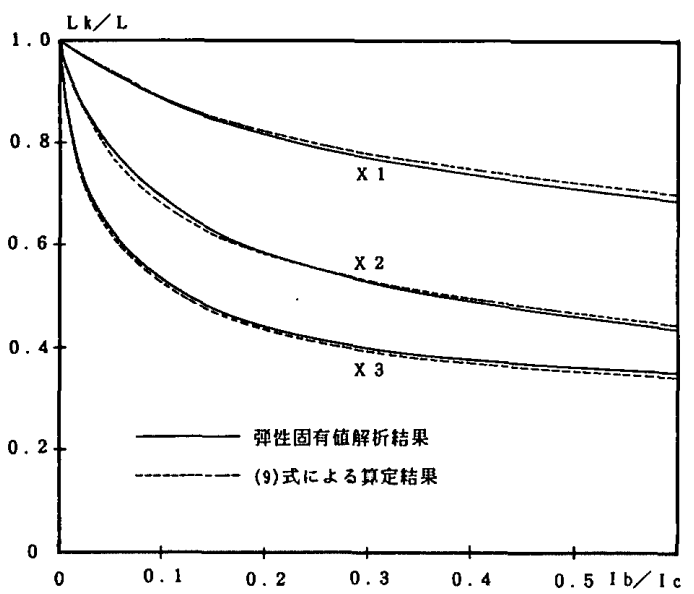

Fig. 11 X型トラス梁における $L_{k} / L-I_{b} / I_{c}$ 関係

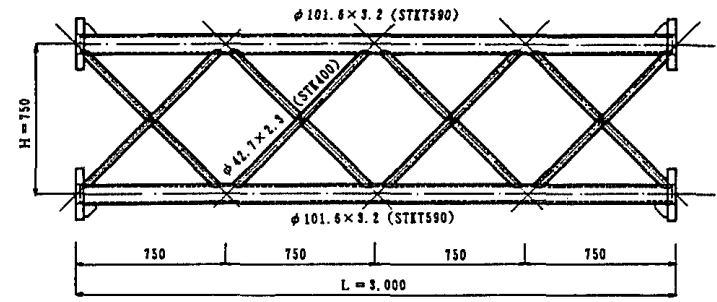

Fig. 12 試験体詳細図（X2 試験体）
また， $X^{\prime}$ 型として弾性固有値解析に基づき算定した 座屈長さ係数が上記試験体と各 $L / H$ ごとほぼ同値とな るような腹材戌性を有するV 型試験体 3 体の併せ 6 体に ついて，文献 21），22）に示す手法を用いた非線形座屈 解析を行うことにより腹材交点部剛節の座屈挙動に及ぼ す影響の差異をみる。

Table 3 に試験体および解析モデルリスト, Fig. 12 に試験体詳細図を示す。

本試験では大スパントラス梁を想定し，弦材にはJIS G 4478 に規定される鉄塔用高張力鋼鋼管 STKT 590 を， 腹材にはSTK 400 を適用する。Table 4 に実験に供し た鋼管部材の材料引張および短柱王縮試験結果を,

Fig. 13 に短柱圧縮試験における応力度一ひずみ度関係曲 線を示す。

\section{2 境界条件および載荷方法}

Fig. 14 に示すように，載荷用骨組＋試験体＋載荷用 骨組の両端をピンローラー支点とし，試験体両端にオイ ルジャッキで鉛直方向力を載荷する 4 点曲げ載荷法によ り中央部武験体に等曲げモーメントを作用させる。この とき，オイルジャッキ頭部には荷重計測用ロードセルと 構面内回転自由の球座を設ける。

トラス梁弦材端部の境界条件は，王縮材となる上弦材 端部は球座を設けることによりねじりを含めたいずれの 方向も回転自由, 引張材となる下弦材端部は骨組に組込 んだ場合を模擬し載荷用骨組とボルトで緊結することに よりいずれの方向も回転拘束の条件とする。なお，載荷 骨組の剛性が試験体の座屈耐力に及ぼす影響は弾性固有

Table 3 試験体および解析モデルリスト

\begin{tabular}{|c|c|c|c|c|c|c|c|}
\hline 名 陈 & 丝财サイス & 眼材サイメ & $\begin{array}{c}\mathrm{L} \\
\text { (cm) }\end{array}$ & 2 & $\begin{array}{l}\mathrm{H} \\
\mathrm{(c \textrm {H } )}\end{array}$ & (dcB) & 㔭要 图 \\
\hline$x_{1}$ & \multirow{6}{*}{$\begin{array}{l}\$ 101.6 \times 3.2 \\
\text { (STKT590\} }\end{array}$} & \multirow{3}{*}{$\begin{array}{c}\phi 12.1 \times 2.3 \\
(S T K 400)\end{array}$} & 150 & 43 & & \multirow{3}{*}{$15^{\circ}$} & Х \\
\hline$\times 2$ & & & 300 & 86 & & & $\triangle \triangle X \triangle$ \\
\hline $\begin{array}{l}x_{3} \\
x \cdot 3\end{array}$ & & & 150 & 129 & 3 & & Хメメメ \\
\hline$v_{1}$ & & \multirow{3}{*}{$\begin{array}{c}\$ 34.0 \times 3.5 \\
(\text { STK } 100)\end{array}$} & 150 & 43 & 10 & \multirow{3}{*}{$63^{\circ}$} & $\triangle$ \\
\hline $\mathrm{v} 2$ & & & 300 & 86 & & & $\triangle \triangle \backsim$ \\
\hline v 3 & & & 450 & 129 & & & $\bowtie \bowtie \bowtie \bowtie$ \\
\hline
\end{tabular}

Table 4. 1 材料引張試験結果

\begin{tabular}{|c|c|c|c|c|c|c|}
\hline 部材サイス & 材些 & $\begin{array}{l}\text { 毁涘片 } \\
\text { 号 }\end{array}$ & $\begin{array}{c}\text { 降伏点 } \\
o y \\
\left(t / \mathrm{cm}^{2}\right)\end{array}$ & 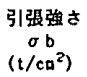 & $\begin{array}{c}\text { 㦀伏比 } \\
\text { Y. R. }\end{array}$ & $\begin{array}{l}\text { 伸 } v \\
\varepsilon \text { 口ax } \\
\text { (\%) }\end{array}$ \\
\hline$\phi 101.6 \times 3.2$ & STIT590 & 12B & 6.11 & 7.11 & 0.86 & 22.3 \\
\hline$\phi \quad 42.7 \times 2.3$ & STK 400 & $12 \mathrm{~A}$ & 3. 51 & 4. 17 & 0.84 & 17.2 \\
\hline
\end{tabular}

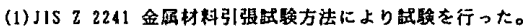

Table 4.2 短柱圧縮試験結果

\begin{tabular}{|c|c|c|c|c|c|c|}
\hline 部材サイズ & 材筫 & $\begin{array}{l}\text { 径骂比 } \\
\mathrm{D} / \mathrm{t}\end{array}$ & $\begin{array}{c}\text { 降伏点 } \\
\sigma y \\
\left(\mathrm{t} / \mathrm{cm}^{2}\right)\end{array}$ & 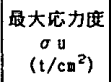 & $\begin{array}{c}\text { 动力上界家 } \\
\sigma \text { U } / \sigma \mathrm{y}\end{array}$ & 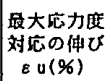 \\
\hline$\phi 101.6 \times 3.2$ & STKTS90 & 32 & 5.75 & 6.40 & 1.11 & 1.25 \\
\hline
\end{tabular}

(1)式駼体最さは3D (铜官外玨)とし，平押しの条件て式顿を行った。 
值解析によりほとんど無視できることを確認している。 また，上下弦材端部の面外方向移動は拘束する。これ より，上弦材は原則として試験体長さを座屈長さとする 両端回転自由の生縮材として取扱える。

4.3 曲げモーメントと弦材ねじれ変形角の関係

Fig. 15 に，(10）式で与えられるトラス梁に作用する 曲げモーメント $M$ と弦材ねじれ変形角 $\beta_{i}$ の関係を示 す。なお, 縦軸 $M$ は（11）式で与えられる降伏モーメ ント $M_{y}$ で除すことにより無次元化を行う。

$$
M=Q \cdot L_{0}
$$

$Q$ ：載荷荷重 $L_{0}$ : 荷重作用点と反力点の水平距離

$$
M_{y}={ }_{c} \sigma_{y} \cdot A_{c} \cdot H
$$

${ }_{c} \sigma_{y}$ ：短柱圧縮試験における弦材の降伏応力度

$A_{c}:$ 弦材の断面積

ここに, 図中の実線はX型の実験結果, ○印プロット 点はX型の非線形座屈解析結果， $\square$ 印プロット点はV型 の非線形座屈解析結果を示す。

なお，非線形座屈解析においては，材軸方向，円周方

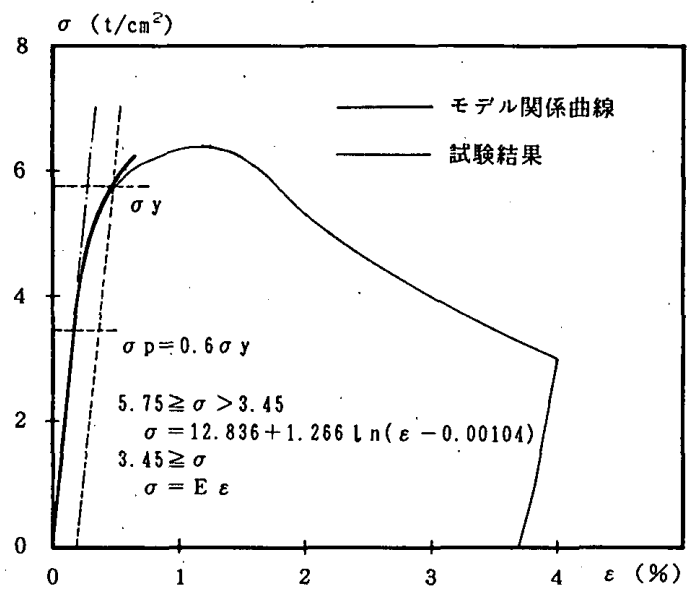

Fig. 13 短柱王縮試験における弦材の $\sigma-\varepsilon$ 関係
向に積分点を有するパイプ断面梁要素を適用し，上弦材 には中央部で試験体測定結果の平均的値である $1 / 1000$ $L$ となる元たわみを正弦波形で与える。また，鋼管部 材の応力度一ひずみ度関係はFig. 13 に太実線で示すモ デル化された関係を用いる。

これより，M- $\beta_{i}$ 関係の初期剛性 $K_{B}$ は，いずれの試 験体においても王縮材である上弦材の方が引張材である 下弦材よりも小さい。また， $K_{B}$ は $L / H$ による差異が 小さいことから，L/H が大きいほど相対的なねじり剛 性は大きいといえる。このことは，L/H が大きいほど $L_{k} / L$ が小さくなることと強い関連があると考えられ る。

$\mathrm{X}$ 型と $\mathrm{V}$ 型の比較において, 初期剛性 $K_{B}$ は上下弦材 とも X 型 $>V$ 型の傾向にある。また，この相対的な差異 は引張下弦材で大きく, V型では若干のねじれ変形が認 められるのに対し，X型では交点部における拘束効果に よりほとんどねじれ変形しないと見なせる。このことは 腹材交点部剛節タイプにおいて $L_{k} / L$ がX型くV型とな る支配的な要因であると判断される。

4.4 構面外変形モード

Fig. 16 に，非線形座屈解析における座屈耐力時のト ラス梁中央部における上弦材位置, 上下弦材中間位置(構 面外変形を正弦波として扱うことにより中央部の值に換 算), 下弦材位置の計 3 点をプロット点とし, $\mathrm{V}$ 型上弦 材の構面外変形量を基準值 1.0 とした場合の構面外変形 モード図を示す。

これより，○印プロット点を実線で結んだX型の方が 口印プロット点を点線で結んだV型より，上下弦材中間 位置における構面外変形拘束の度合いが大きい。

4.5 曲げモーメントと構面内回転角の関係

Fig. 17 に，トラス梁に作用する曲げモーメント $M$ を

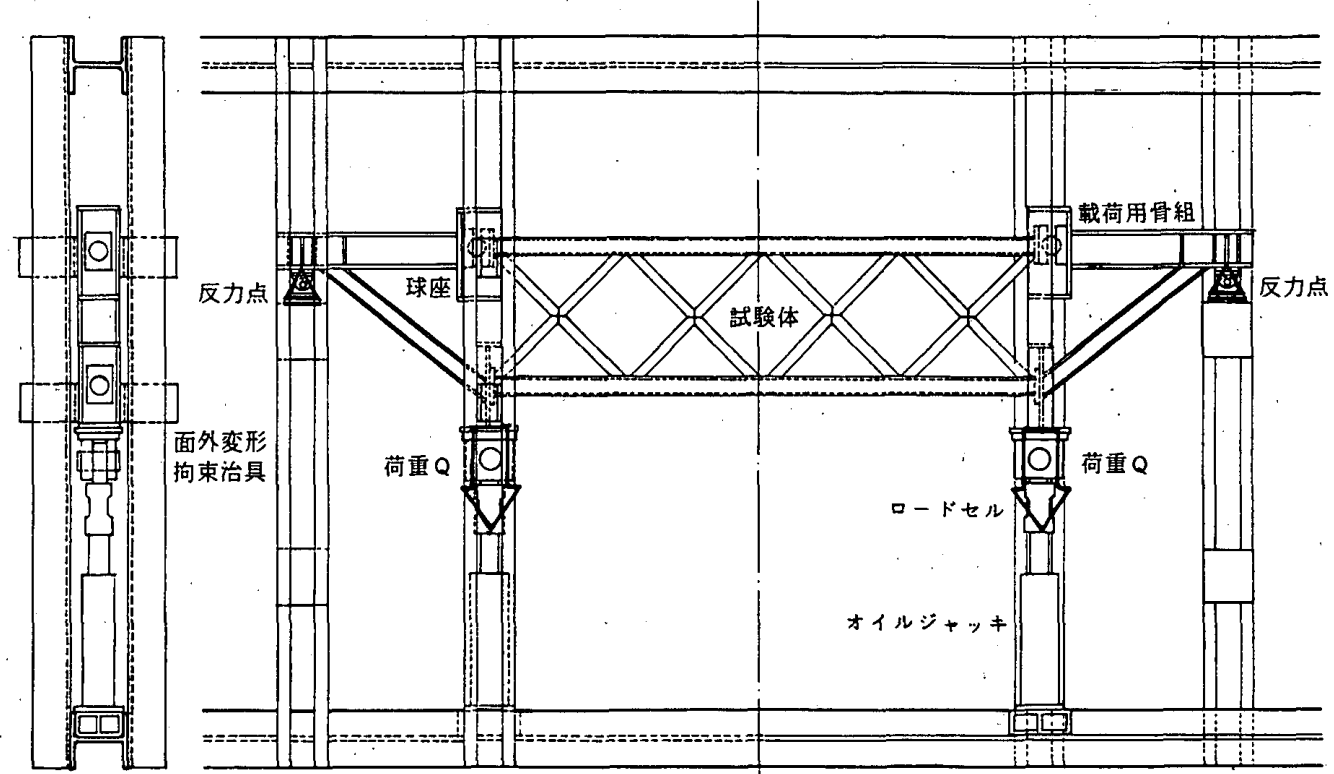

Fig. 1.4 載荷装置概要図 
降伏モーメント $M_{y}$ で除した值 $M / M_{y}$ と（12）式で与 えられる回転角 $\theta$ を $M_{y}$ に対応する弾性回転角 $\theta_{y}$ で無 次元化した $\theta / \theta_{y}$ の関係を示す。
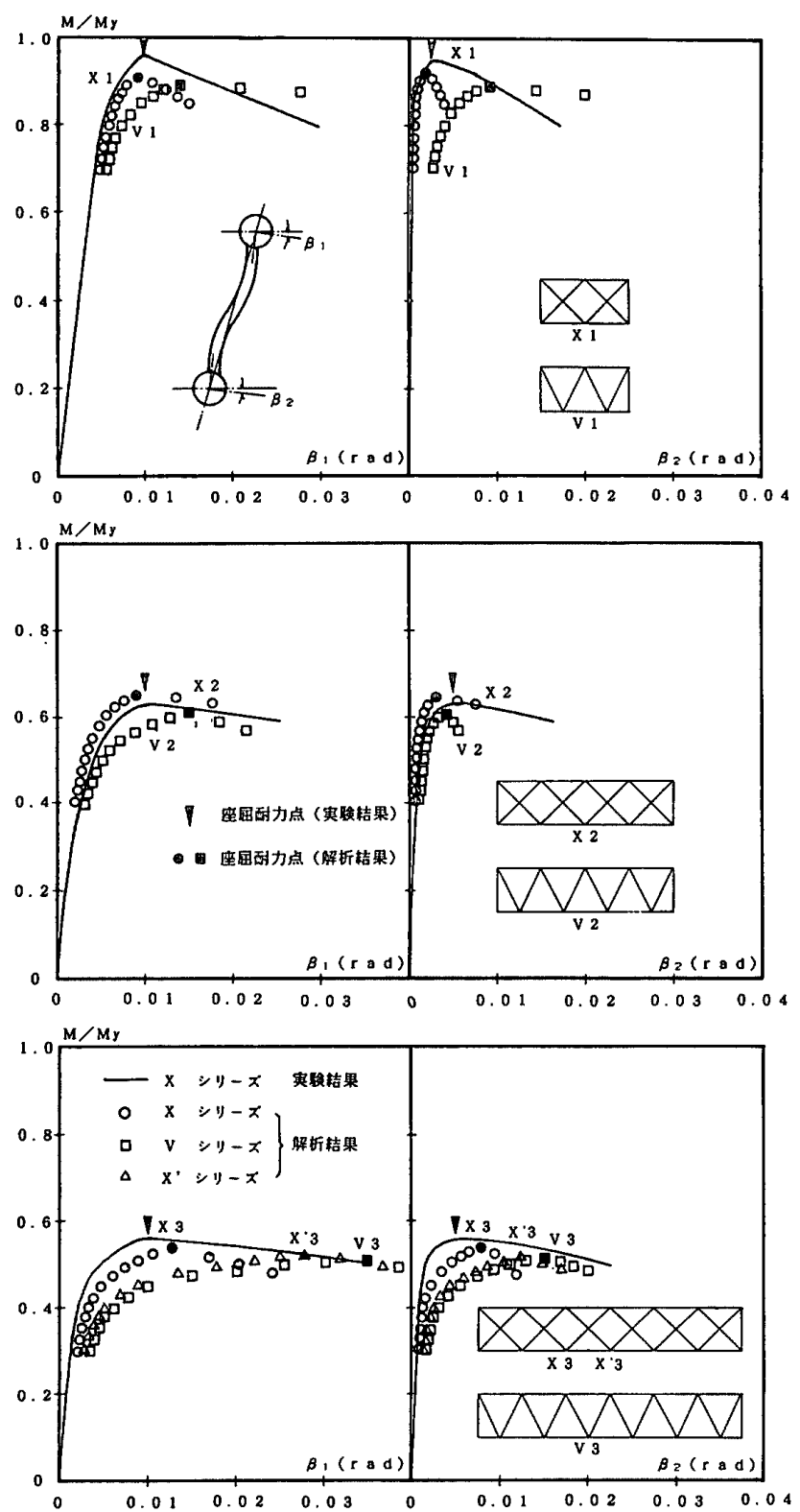

Fig. $15 M / M_{y}-\beta$ 関係
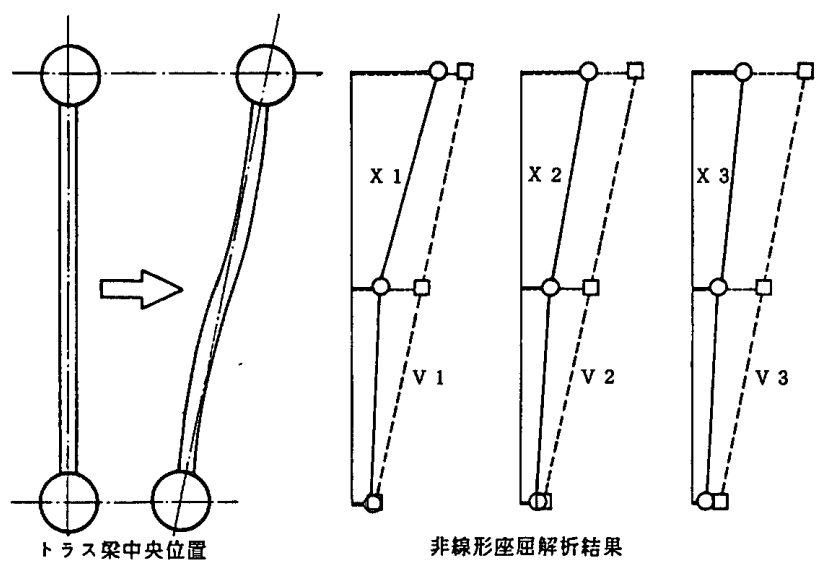

Fig. 16 來屈耐力時の構面外変形モード

$$
\theta=\left(2 \delta_{m}-\delta_{e 1}-\delta_{e 2}\right) / L
$$

$\delta_{m}:$ 試験体中央部鉛直方向変位量

$\delta_{e i}:$ 試験体端部鉛直方向変位量

ここに，図中の実線はX型の実験結果，○印プロット 点はX型の非線形座屈解析結果， $\square$ 印プロット点はV型 の非線形座屈解析結果を示す。

これより，L/H が小さいほど弦材の構面外細長比が 小さくなることから座屈耐力（実験結果においては最大 耐力二座屈耐力と定義）は大きくなる。また，いずれの
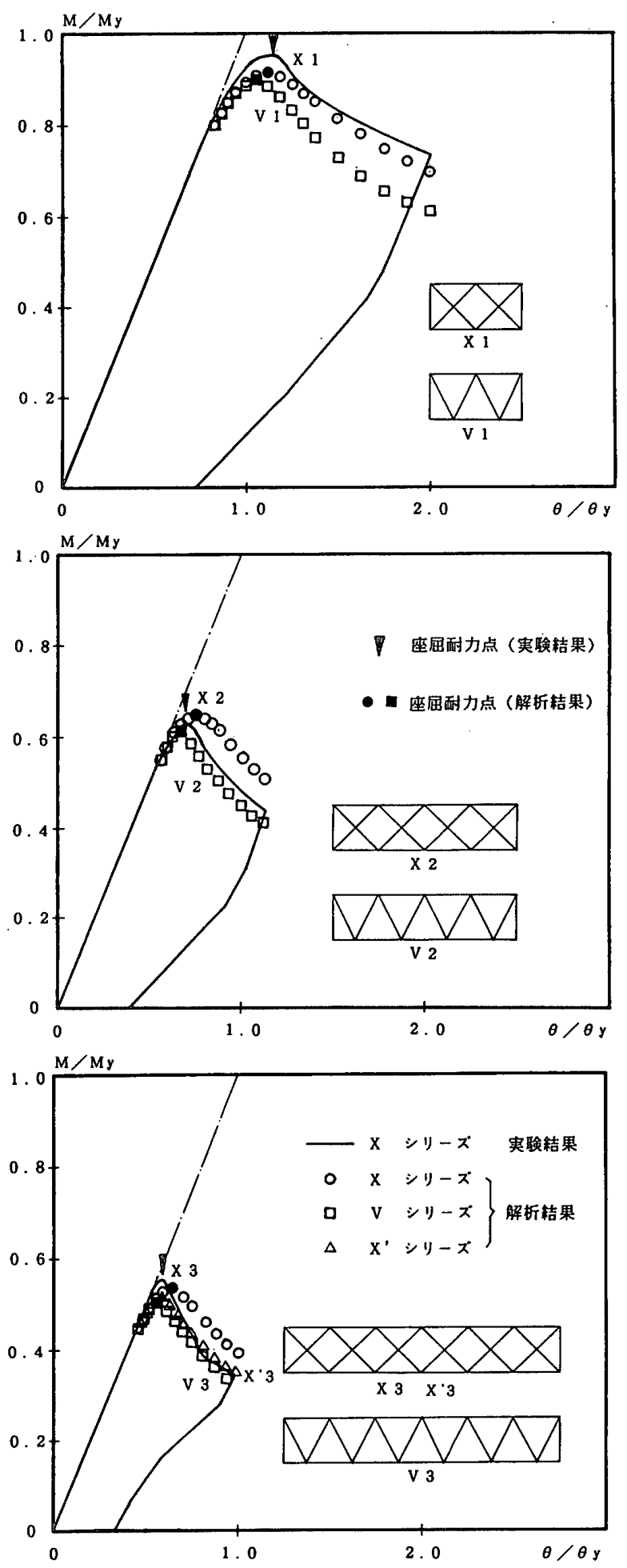

Fig. $17 M / M_{y}-\theta / \theta_{y}$ 関係 
$L / H$ においても座屈耐力はX型 $>\mathrm{V}$ 型となる。

また，Fig.15，Fig.17において，O印プロット点で 示す X型の非線形座屈解析結果は座屈耐力および変形性 状両面において実線で示す実験結果とおおむね良い対応 を示すことが確認される。なお，構面外細長比 129 のシ リーズにおいて，参考までに $X^{\prime}$ 型 ( $X^{\prime} 3$ 試験体) の非 線形座屈解析結果を $\Delta$ 印プロット点で示すが，3章にお ける弾性固有值解析結果からも推察されるように， 口印 プロット点で示すV3 とほぼ同様の座屈挙動を示す。

\section{6 弦材の座屈長さ係数評価}

Fig: 18 に座屈弦材の态力度 $\sigma$-接線係数 $E_{t}$ 関係を示 す。ここに，太実線はFig.13における結果を，細一点 鎖線は鋼構造設計規準の許容圧縮応力度式から導かれた

（5）式から求められる結果を示す。

また，Fig. 19 に弦材の座屈応力度 $\sigma_{c r}$-細長比 $\lambda$ 関係 を示す。ここに，太実線はFig. 18 から求まる（13）式 に示す関係を示す。また，太点線は高張力鋼管柱の素材 に関する実験資料がそしいことから，文献 25）に示さ れる STK 400 冷間成形鋼管部材を対象とした径厚比 30
の中心圧縮柱における強度確率分布の平均値を用い, 規 格降伏点を $4.5 \mathrm{t} / \mathrm{cm}^{2}$ として算定した結果を示す。細点 線は統計的手法において下限値に相当すると見なせる鋼 構造限界状態設計規準. (案) ・同解説 ${ }^{26}$ における曲げ座 屈耐力式の基本式における関係を，細一点鎖線は（5） 式の関係を参考までに示す。矢印で示す弦材応力度 $\sigma_{c r}$ は実験および非線形解析結果を示す。

$$
\begin{aligned}
& \sigma_{c r}=12.834+1.265 \ln \left\{12.498 /\left(\sigma_{c r} \lambda^{2}\right)\right\} \\
& \sigma_{c r}: \text { 座屈応力度 }\left[\text { 単位 } \mathrm{t} / \mathrm{cm}^{2}\right. \text { ] } \\
& \lambda_{c} \leqq 0.15 \quad \sigma_{c r}={ }_{c} \sigma_{y} \\
& 0.15<\lambda_{c} \leqq 1.29 \quad \sigma_{c r}=\left\{1-0.5 / 1.14\left(\lambda_{c}-1.29\right)\right\}_{c} \sigma_{y} \\
& 1.29<\lambda_{c} \quad \sigma_{c r}=1 /\left(1.2 \lambda_{c}^{2}\right) \\
& \lambda_{c}=\lambda / \sqrt{\pi^{2} E / c \sigma_{y}} .
\end{aligned}
$$

Fig. 20 に, この矢印で示す座屈応力度と $\sigma_{c r}-\lambda$ 関係 曲線との交点に対応する細長比 $\lambda_{c r}$ の所定の構面外細長 比 $\lambda$ に対する比として与えられる座屈長さ係数 $L_{k} / L$ と,（7）式（9）式により求まる算定結果との比較図 を示す。ここに, 図中の黒塗りのプロット点は (13) 式 による評価結果，白抜きのプロット点は文献 25）に基

\begin{tabular}{|c|c|c|c|c|c|c|c|c|c|c|c|c|c|c|}
\hline \multirow{3}{*}{$\begin{array}{l}\text { 武镍体 } \\
\text { 多 } \\
\text { 称 }\end{array}$} & \multirow{3}{*}{$\begin{array}{c}\text { 降伏荷面 } \\
\text { Py } \\
(\mathrm{t})\end{array}$} & \multirow{3}{*}{$\begin{array}{c}\text { 弦想 } \\
\text { 稩長比 } \\
2 \\
2\end{array}$} & \multirow{3}{*}{$\begin{array}{c}\text { オイラ一 } \\
\text { 座屈荷再 } \\
\text { EP cr } \\
\text { (t) }\end{array}$} & \multirow{3}{*}{ 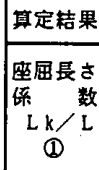 } & \multicolumn{2}{|c|}{ 固有值解析䊅果 } & \multicolumn{4}{|c|}{ 非形座届解折桔果 } & \multicolumn{2}{|r|}{ 实 锒 } & \multicolumn{2}{|c|}{ 耤 果 } \\
\hline & & & & & \multirow{2}{*}{ 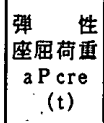 } & \multirow{2}{*}{ 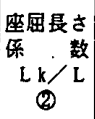 } & \multirow{2}{*}{$\begin{array}{l}\text { 非形 } \\
\text { 座屈荷重 } \\
\text { a P crp } \\
\text { (t) }\end{array}$} & \multirow{2}{*}{$\begin{array}{l}\text { a } \mathrm{P} \operatorname{crp} \\
/ \mathrm{Py}\end{array}$} & \multicolumn{2}{|c|}{$\begin{array}{c}\text { 座届長さ䋆数 } \\
\mathrm{L} / \mathrm{k} / \mathrm{L}\end{array}$} & \multirow{2}{*}{$\begin{array}{c}\text { 坐㢆荷重 } \\
\text { eP cr } \\
\text { (t) }\end{array}$} & \multirow{2}{*}{$\begin{array}{l}\mathrm{ePcr} \\
/ \mathrm{Py}^{2}\end{array}$} & \multicolumn{2}{|c|}{$\begin{array}{c}\text { 座屈長さ係数 } \\
\mathrm{L} k / \mathrm{L}\end{array}$} \\
\hline & & & & & & & & & (3)-1 & (3) -2 & & & (4)-1 & (4)-2 \\
\hline$\times 1$ & \multirow{7}{*}{56.9} & 43 & 109.4 & 0.95 & 121.4 & 0.95 & 52.5 & 0.92 & 0.70 & 0.90 & 54.0 & 0.95 & 0.64 & 0.83 \\
\hline$\times 2$ & & 86 & 27.7 & 0.78 & 44.2 & 0.79 & 37.0 & 0.65 & 0.16 & 0.80 & 36.0 & 0.63 & 0.81 & 0.83 \\
\hline$\times 3$ & & 129 & 12.3 & 0.62 & 32.8 & 0.61 & 31.0 & 0.54 & 0.63 & 0.62 & 32.0 & 0.56 & 0.62 & 0.60 \\
\hline$v_{1}$ & & 43 & 109.4 & 0.98 & 114.0 & 0.98 & 50.5 & 0.89 & 0.17 & 0.96 & & & & \\
\hline v 2 & & 86 & 27.7 & 0.84 & 39.0 & 0.84 & 35.0 & 0.62 & 0.86 & 0.84 & & & & \\
\hline v 3 & & \multirow{2}{*}{129} & \multirow{2}{*}{ 12: 3} & \multirow{2}{*}{0.66} & 30.0 & 0.65 & 29.0 & 0.51 & 0.65 & 0.64 & & . & & \\
\hline$\times 3^{\prime}$ & & & & & 30.5 & 0.61 & 29.5 & 0.52 & 0.65 & 0.63 & & & & \\
\hline
\end{tabular}

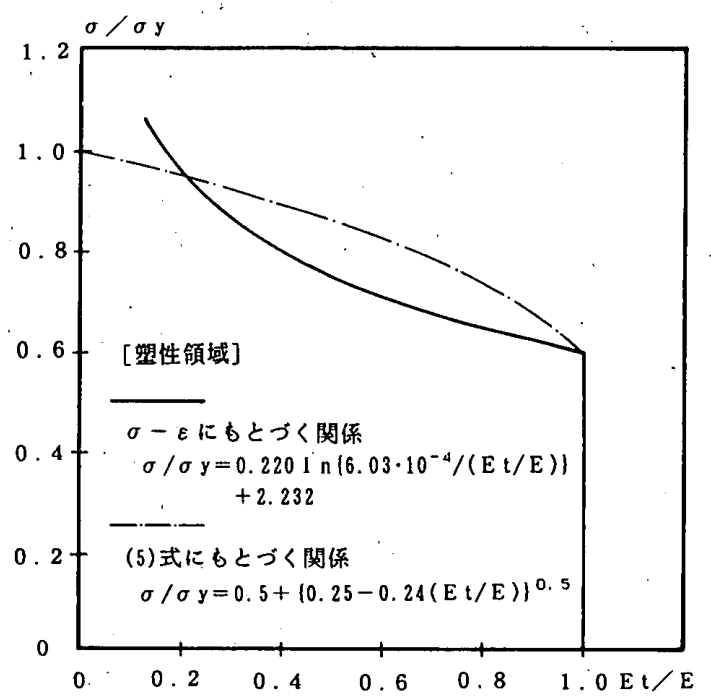

Fig. 18 弦材の $\sigma / \sigma_{y}-E_{t} / E$ 関係

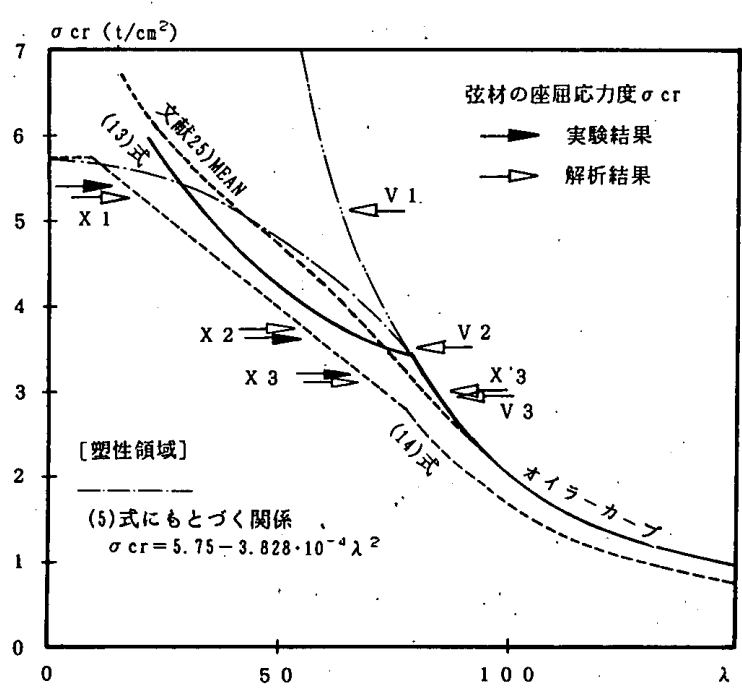

Fig. 19 弦材の $\sigma_{c r}-\lambda$ 関係

Table 5 弦材の座屈長さ係数一覧表

1) (は，本研究で提案した座風長さ評価式，V型，X·型は(7)式，X型は(9)式にもとづいて其定した值を示す。

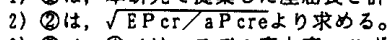

3）(3)-1，(4)-1は，モデル応力度ーひずみ度関係から与えられる座屈疬力度一湅長比関釈式(12)式を用いて算定した值を示す。

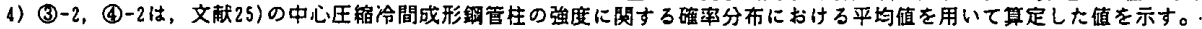


づく評価結果を示す。Table 5 に座屈長さ係数一覧表を 示す。

これより，（7）式，（9）式による座屈長さ係数算定 結果は，短柱圧縮試験結果を用いて整理した（13）式に よる評価結果と座屈弦材の構面外細長比が 86,129 と大 きい場合には良い対応を示す。これに対し細長比が 43 と小さい場合には差異が見られるが安全側評価を与え る。また, 製作方法による残留応力, 初期たわみ, 載荷 時の偏心等の影響を統計的に評価した文献 25）に基づ く結果とは, 細長比にかかわらずおおむね良い対応を示 すことが確認される。

なお, 細長比 $\lambda$ に対する座屈応力度 $\sigma_{c r}$ の比較におい て，(14）式く(13）あるいは文献 25）に基づく関係に あることから（（7) 式，（9）式による算定結果は (14) 式による評価結果に対し安全側評価を与える。

本研究が対象としている等曲げモーメントトラス梁に おいては, 塑性化する部材は弦材に限定される。また, 腹材軸力は原則として0であり, 弦材が塑性化した場合 においても腹材剛性は変化しないものと見なせる。した がって, 塑性座屈時の腹材の弦材に対する剛性比 $E I_{b} /$ $E_{t} I_{c}$ は $I_{b} / I_{c}$ より大きくなり，弾性固有值解析に基づく （7）式,（9）式による算定結果は, 実験および解析 結果に対して安全側評価を与える傾向にあると考えられ る。

以上より, 座屈弦材の材料特性にかかわらず, また塑 性座屈領域まで包含した範囲において，（7）式（9） 式による算定方法は有効であるといえる。

\section{5. まとめ}

等モーメント忍力状態かつ王縮弦材端部は構面内回 転, ねじり回転共自由, 引張弦材端部は構面内回転, ね じり回転共拘束, 構面外変形はいずれの材端においても

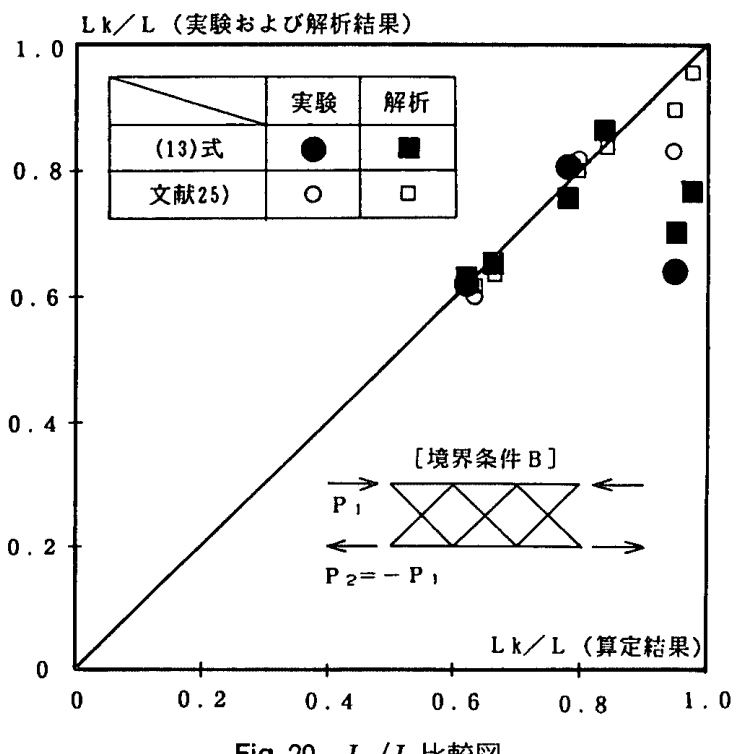

Fig. $20 L_{k} / L$ 比較図
拘束の境界条件における，分岐継手タイプ鋼管トラス梁 の横座屈耐力に関する本研究より得られた成果を以下に 列挙する。

(1) 弾性固有值解析結果に基づき，文献 5)，6）の工ネ ルギー法による横座屈耐力式を補正する方法でV型トラ ス梁弦材の横座屈長さ評価式を導いた。

$$
\begin{aligned}
L_{k} / L= & {\left[1+4\{L /(\pi H)\}^{2} \delta C_{c} / B_{c}\right.} \\
& \left.+3\{L /(\pi H)\}^{3}\left(B_{w}+C_{w}\right) / B_{c}\right]^{-1 / 4} \\
\delta=1 /\{1 & \left.+C_{c} /\left(3 / 2 B^{\prime}\right)\right\} \cdots \cdots \cdots \cdots \cdot \text { (本文 }(7) \text { 式) }
\end{aligned}
$$

(2) X型トラス梁の腹材交点部剛節の横座屈耐力に及ぼ す影響を弾性固有值の比較から定量的に把握するととも に，(1)と同様な手法により，この影響を考虑したX型卜 ラス梁弦材の横座屈長さ評価式を導いた。

$$
\begin{array}{r}
L_{k} / L=\left[1+15\{L /(\pi H)\}^{3}\left(B_{w}+C_{w}\right) / B_{c}\right]^{-1 / 4} \\
\cdots \ldots \ldots \ldots \ldots \cdots \cdots \cdots(\text { 本文 }(9) \text { 式) }
\end{array}
$$

ただし，(7) 式（9) 式の適用範囲は, 本研究対象 の $2 \leqq L / H \leqq 6 ， I_{b} / I_{c} \leqq 0.6$ に限定される。

(3) X型トラス梁の横座屈試験を行い, 弦材横座屈長さ 評価式における腹材交点部剛節の影響を考慮した等価剛 性評価の妥当性および評価式の塑性座屈領域への拡張展 開の有効性を確認した。

\section{参考文献}

1）坪井善勝, 若林 実: 架構梁の横座屈に於ける弦材のね じれ抵抗の影響, 日本建築学会構造系論文報告集, 第 38 号, pp. 40〜44, 1949

2）鈴木敏郎：ウェププレートの変形と座屈（鎆管組立梁の 横座屈), 日本建築学会構造系論文報告集, 第 69 号, pp. 717 720, 1961

3）鈴木敏郎：トラスの横座屈 I一理論式の誘導一, 日本建 築学会関東支部研究報告, 第 29 号, 1961

4）鈴木敏郎：トラスの横座屈 II一偏心王縮実験一, 日本建 築学会関東支部研究報告, 第 29 号, 1961

5）鈴木敏郎：鉄骨トラスの横座屈，日本建築学会構造系論 文報告集，第 70 号, pp. 10 15, 1962

6）鈴木敏郎：鋼管トラス梁の横座屈, 日本建築学会構造系 論文報告集，第 96 号, pp. 7 12, 1964

7）藤本盛久，難波恒夫：鋼管卜ラスの面外座屈，日本建築 学会構造系諭文報告集, 第 89 号, p. 129,1963

8）森 宣制：鋼管組立材の横方向の安定性，土木学会論文 集, 第 111 号, pp.1 10, 1964

9）若林 実, 西村富美子：エネルギー法によるトラス横座 屈の解析, 日本建築学会大会学術講演梗概集, pp. 309 310,1971

10）森野捷輔： $n$ 格間ごとに横補剛された鉄骨トラスばりの 王縮弦材の有効座屈長さ, 日本建築学会大会学術講演梗 概集, pp. 1393 1394，1977

11）森野捷輔：鉄骨トラスばり圧縮弦材の構面外座屈耐力の 略算一節点荷重の影響一，日本建築学会四国・九州支部 研究報告, 第 4 号, 1978

12）松井千秋，南島雄二：剛節平面トラスの横座屈に関する 研究 (座屈荷重に与えるウェブ材の補剛効果について), 
日本建築学会大会学術講演梗概集, pp. 793 794, 1975

13）、松井千秋, 津田恵吾 : 非充腹材の弾性横座屈荷重につい て, 日本建築学会九州支部研究報告, 第 23 号, 1977

14）松井千秋, 森野捷輔, 新宅浩明：非充腹柱の曲げねじれ 座屈に及ぼす節点局部変形の影響について，日本建築学 会大会学術講演梗概集；pp. 1063 1064，1979

15）松井千秋, 森野捷輔, 河野昭彦, 清水知史：仕縮軸力之 曲げを受ける鎆管トラス柱の曲げねじれ座屈実験, 日本 建築学会大会学術講演梗概集, pp. 2099 2100, 1981

16）松井千秋, 森野捷輔, 河野昭彦, 貞広 修: 壬縮軸力と 曲げを受ける鋼管トラス柱の曲げねじれ座屈実験（その 2 ), 日本建築学会九州支部研究報告, 第 26 号, 1982

17）松井千秋, 森野捷輔, 河野昭彦, 貞広 修: 壬縮軸力と 曲げを受ける鋼管トラス柱の曲げねじれ座屈実験（その 4 )一曲げモーメント勾配の影響一, 日本建築学会九州支 部研究報告，第 27 号, 1983

18）松井千秋，森野捷輔，河野昭彦：円形鋼管トラス柱の曲 げねじれ座屈に関する実験的研究, 日本建築学会構造系 論文報告集，第 363 号, pp. 12 21, 1986
19）松井千秋，河野昭彦：鋼管トラス柱の曲げねじれ座屈に 対する設計法, 構造工学論文集, Vol. 34 B , 1988

20）坂本 傑，套島仲男：八角形鋼管分岐継手の力学性状, 日本建築学会大会学術講演梗概集, pp. 1037 - 1038, 1979

21）鈴木敏郎, 佐藤亘宏, 深沢 隆：塔状卜ラス骨組脚部の 座屈耐力に関する研究, 日本建築学会構造系論文報告集, 第 412 号, pp. $67 \sim 77,1990$

22）鈴木敏郎, 小河利行, 石田俊久, 五十嵐規矩夫：剛接合 単層トラスドームの弾塑性座屈解析, 日本建築学会大会 学術講演梗概集, pp. 1285 1286, 1990

23）銅管構造設計施工指針・同解説，日本建築学会

24）鋼構造設計規準 - 同解説, 日本建築学会

25）越智健之, 黒羽啓明: ‘冷間成形冈形鋼管部材の䩂力之変 形能の統計的評価, 日本建築学会構造系論文報告集, 第 391 号, pp. 59 70, 1985

26）鋼構造限界状態設計規準 (案) - 同解説, 日本建築学会

(1992 年 1 月 10 日原稿受理, 1992 年 6 月 8 日採用決定) 